\title{
MEASURING PSYCHOSOCIAL TRAUMA: A NEW INSTRUMENT
}

\author{
Loreto Villagrán \\ Universidad de Concepción \\ Amalio Blanco, Universidad Autónoma de Madrid \\ Julio Olea, Universidad Autónoma de Madrid \\ Marian Bilbao, Universidad Alberto Hurtado
}

Correspondence concerning this article should be addressed to Loreto Villagrán, Department of Psychology, Social Sciences Faculty, Universidad de Concepción, Victor Lamas 1290, Concepción, Chile Contact: lorevillagran@udec.cl

\begin{abstract}
Keywords: Factor Analysis: Exploratory, War/armed conflict as civilian, Community violence, Interpersonal trauma, PTSD phenomenology, Prisoners, Refugees
\end{abstract}

\begin{abstract}
The aim of this study was the design and validation of a Psychosocial Trauma Scale (PSTS). This instrument tried to capture the following theoretical dimensions: Pretraumatic Situation, Destruction of Fundamental Beliefs; Intergroup Emotions, and Family and Community Destruction. In a first phase, we gather evidence for the items designed through content validation with experts. In a second phase, we explore the structure with EFA, reducing the number of items. The last phase was a divergent validation, applying the short version of PSTS with other validation scales (symptomatology of post-traumatic
\end{abstract}


stress, psychological well-being, and social well-being). METHOD. A cross-sectional study was conducted, consisting of 382 individuals affected by political violence: civil war in El Salvador, forced displacement from Colombia, and victims of state violence from Chile. RESULTS. The content validation utilized 81 forms with 146 original items. Exploratory factor analysis showed that the PSTS had an internal structure partially differing from the one proposed, with two new emerging dimensions: Destruction of Sociality and Personal and Collective Self-Efficacy. The four dimensions found for PSTS were Pre-traumatic Situation, Destruction of Sociality, Personal and Collective Self-Efficacy and Intergroup Emotions. To examine divergent validity, we correlated these dimensions by using three different instruments, which showed coherent results. DISCUSSION. The dimensions of psychosocial trauma would complement PTSD or clinical measures. Future studies should expand and broaden the study of the psychosocial consequences of collective violence together with the properties of the presented instrument.

Keywords: Factor Analysis: Exploratory, War/armed conflict as civilian, Community violence, Interpersonal trauma, PTSD phenomenology, Prisoners, Refugees 


\section{Introduction}

The most common and extreme suffering humankind has experienced throughout history comes from the intentionally planned actions of human beings against their fellow man, in which most of those suffering are innocent victims. Since 1980, when the DSM-III decided to propose posttraumatic stress disorder (PTSD) as a new diagnostic category for mental disorders, there has been robust agreement: "the disorder may be especially severe or long-lasting when the stressor is interpersonal and intentional" (American Psychiatric Association, 2013, p. 275). This is the only feature of PTSD that has remained unchanged since the DSM-III. At that time, Martín-Baró (1990; 2003), taking as a starting point the Civil War in El Salvador (1980-1992), and the ILAS Group from therapeutic practice, considering victims of torture and political repression in Chile under Pinochet's dictatorship (ILAS, 1990; Lira, 1994), came to the conclusion that in addition to the personal damage, the man-made stressor rooted in collective violence reflects and arises from some dysfunctions in the social process introducing fear and interpersonal mistrust as a shared means of controlling political behavior. These are the factors underlying psychosocial trauma as "a normal result of a social system based on a dehumanizing network of social relationships characterized by exploitation and oppression. In other words, psychosocial trauma can be part of a 'normal abnormality” (Martín-Baró, 2003, p. 295).

In the last two decades, the psychosocial after effects of collective violence have been widely confirmed in different cultural settings, in a particular way in social settings marked by a long-lasting violence. Examples of these consequences can be found around the world in the experience of Palestine (Peltonen, Qouta, El Sarraj \& Punamäki, 2010), Sri Lanka (Somasundaram, 2005), and Spain (Díaz, Stavraki, Blanco \& Bajo, 2018; Vázquez, 
2005). studies on the psychosocial consequences of collective violence have also been carried out In Latin America in countries such as Colombia (e.g., Blanco \& Amarís, 2014; Centro Nacional de Memoria Histórica, 2013; Médicos Sin Fronteras, 2013), Guatemala (e.g., Oficina de Derechos Humanos del Arzobispado de Guatemala (ODHAG), 1998), Chile (ILAS, 1990; Madariaga, 2002), Argentina (Robben, 2008), and Nicaragua (Sveaass, 2000). In some way, all of these studies understand psychosocial trauma as a collective trauma "that is more than the suffering experienced by each individual because it cracks all social ties, destroys the identities of groups, undermines any sense of belonging to the community and generates cultural disorientation as the meanings taken for granted become obsolete" (Robben, 2008, p. 403). The implications go beyond the loss of life or physical harm: "the devastation of the social and cultural fabric, the people's history, their identity and value systems are under threat" (Pedersen, 2002, p. 181). All these consequences are equally visible in ethnic and racial conflicts (Whitbeck, Adams, Hoyt \& Chen, 2004; Brave Heart, Chase, Elkins, \& Altschul, 2011; Comas-Díaz, Nagayama \& Neville, 2019), discrimination of ethnic minority persons (Freitas et al., 2018) and in refugee camps (Braun-Lewenshon \& Al-Sayed, 2018). These traumatic experiences are linked to a concatenation of painful losses such the brake of social networks, the loss of cultural values such as language, the erosion of traditional family and community, etc.

Taking the theoretical contributions of Martín-Baró (2003) of the ILAS Group (1990; Lira, 1994) and the results obtained in the aforementioned investigations as a starting point, it has been possible to differentiate four dimensions of psychosocial trauma (Blanco, Díaz \& del Soto, 2006; Blanco, Blanco \& Díaz, 2016): a) the Pre-Traumatic Situation: conditions and events that turn people into victims; b) Destruction of Fundamental Beliefs as a result of exposure to or because of traumatic events: loss of self- 
confidence and loss of confidence in others and in the society in which you live, selfcriticism, etc.; c) the emergence of negative Intergroup Emotions: resentment, hatred, desire for revenge; and d) Family and Community Destruction: networks of protection and support.

Table 1

The four dimensions of psychosocial trauma (Blanco, Blanco \& Díaz, 2016; Villagrán, 2016)

\begin{tabular}{|c|c|}
\hline Dimension & Definition \\
\hline $\begin{array}{l}\text { Pre-traumatic } \\
\text { Situation }\end{array}$ & $\begin{array}{l}\text { Situations, conditions or previous experiences that are part of one's } \\
\text { autobiographical memory and that are perceived or interpreted as } \\
\text { directly responsible for the traumatic experience and/or continue to } \\
\text { maintain it over time. }\end{array}$ \\
\hline $\begin{array}{l}\text { Destruction of } \\
\text { Fundamental } \\
\text { Beliefs }\end{array}$ & $\begin{array}{l}\text { Subjective perception that traumatic events have very deeply affected, } \\
\text { and continue to affect in your case, values and beliefs on which } \\
\text { personal and social life is based. }\end{array}$ \\
\hline $\begin{array}{l}\text { Intergroup } \\
\text { emotions }\end{array}$ & $\begin{array}{l}\text { Emotional reactions of the victims with respect to themselves, both } \\
\text { personally and collectively, and especially with regard to those who } \\
\text { understand (perceive) that they are responsible for the event or events } \\
\text { that have given rise to their traumatic experience (the perpetrators). }\end{array}$ \\
\hline $\begin{array}{l}\text { Family and } \\
\text { community } \\
\text { destruction }\end{array}$ & $\begin{array}{l}\text { Perception that, as a result of the presence and maintenance of } \\
\text { violence, fear and terror have spread, family life and social networks } \\
\text { have deteriorated, interpersonal trust has diminished and participation } \\
\text { in community activities has been paralyzed, leaving everything it } \\
\text { recorded in the collective memory. }\end{array}$ \\
\hline
\end{tabular}

These dimensions have helped us build a scale to assess psychosocial trauma (Psychosocial Trauma Scale, PSTS). This scale joins the "Historical Loss Scale" (Whitbeck et al., 2004), which measures the frequency of an individual's thoughts about their historical, cultural and family losses and the "Historical Loss Associated Symptoms" (Whitbeck et al., 2004), which measures the frequency of emotions experienced when thinking or remembering historical losses. 
The aim of this study was to validate the psychosocial trauma scale (PTSD) created to evaluate the consequences of collective violence. Validation was carried out in three phases: a content validation, an internal structure and reliability validation, and a convergent and divergent validation.

\section{Method}

\section{Participants}

In the initial phase of content validation, 16 experts (judges) were chosen to evaluate the proposed items; the experts came from such fields as clinical psychology, social psychology and political violence and were from Spain, Colombia, El Salvador and Chile. In the second and third phases, in order to evaluate the internal structure and reliability and the divergent validity of the PSTS, the sample was comprised of 406 participants, aged between 18 and 85 years $(M$ age $=43.03, S D=16.01)$, directly affected by political violence: 76 affected by state violence in Chile $(M$ age $=52.95, S D=18.13)$; 254 Colombians affected by forced displacement $(M$ age $=37.64, S D=14.15)$; and 76 excombatants of the El Salvador civil war injured in combat ( $M$ age $=51.38, S D=10.79)$. After eliminating the missing data, only 382 participants remained to participate in the analyses.

\section{Procedure}

In the initial phase of content validation, a review of the scientific literature was conducted, and 142 items were created which corresponded to the dimensions of the psychosocial trauma proposed by Blanco, Blanco \& Díaz (2016) and defined by Villagrán (2016). These items were sent via email to the judges, along with the dimension definitions. After analyzing the answers through the concordance indicator of each item with the proposed dimensions (Rovinelli \& Hambleton, 1977) and relevance with the TPS construct, 
a version of the PSTS was obtained in order to then apply to those affected by violence. In Chile, the participants belonged to the Program of Reparation and Integral Attention in Health and Human Rights (PRAIS), which cares for victims or relatives of disappeared or executed individuals and for political prisoners. In Colombia, the PSTS was applied through the "Nuevo Amanecer" Foundation that works with internally displaced persons, and in El Salvador, it was administered through the "War Cripple Association of El Salvador" (ALGES). All of the participants were informed about the objective of the study, signed the corresponding informed consent form, and were given all the time needed to answer the questions. All the ethical standards proposed by the Declaration of Helsinki (1964), updated in 2013 (WMA, 2013), were followed, and the study was approved by the Ethics Committee of the Pontificia Universidad Católica de Chile.

\section{Measures}

\section{Phase Content Validity}

Judges were given an item evaluation booklet containing instructions, definitions of the psychosocial trauma dimensions (see Table 1) and the 142 scale items. Item congruence (IC) was evaluated with one of the four dimensions, according to Rovinelli \& Hambleton (1977). The response format was: -1 , does not correspond to the dimension; 0, indecisive; 1, corresponds. In addition, item relevance (IP) to the psychosocial trauma construct was evaluated. The response format ranged from 1 (the item has little relevance or is not relevant); to 10 (very relevant item). In addition, there was a section of qualitative comments.

\section{Validity of the Internal Structure of the PSTS}

Psychosocial Trauma Scale (PSTS). After the first phase of the study, the PSTS comprised 81 Likert items, with 7 ordered categories $(1=$ totally disagree, to $7=$ totally 
agree). The first dimension measures the Pre-traumatic Situation (which asks participants to remember the time when the events occurred). The remaining 60 items address the evaluation of the consequences at the current moment, with statements that represent the dimensions of Destruction of Fundamental Beliefs (27 Items), Intergroup Emotions (14 Items), and Family and Community Destruction (19 items). Cronbach's alpha values for the subscales ranged from .81 to .93 (see Table 2). Confirmatory factor analysis showed an acceptable Model Fit $\left(\chi 2_{(1797)}=3384.947, \mathrm{p}<0.001 ; \mathrm{CFI}=0.823 ; \mathrm{TLI}=0.814 ; \mathrm{NNFI}=\right.$ 0.814; PNFI $=0.654 ;$ SRMR $=0.071 ;$ RMSEA $=0.050(90 \%$ CI $[0.047,0.052])$.

\section{Convergent and Divergent Validity of the PSTS}

The Global Assessment of Post-traumatic Stress (EGEP, Crespo \& Gómez, 2012) evaluates the symptomatology of PTSD in adults exposed to traumatic experiences according to DSM-IV R and DSM 5 criteria. The items of Reexperimentation (5 items), Avoidance and Affective Dullness (7 items), Hyperactivation (5 items), and Subjective Clinical Symptoms (5 items) were applied. The response format used the original $0=$ "No" and $1=$ "Yes" responses, for which the latter corresponded to the existence of symptoms. In addition, discomfort degree was assessed: from $0=$ none to $4=$ extreme. The internal structure of the scale presented two dimensions: Cognitive Alterations $(\alpha=0.89)$ and Mood Alterations $(\alpha=0.87)$, explaining $40.19 \%$ of the sum of squared saturations.

Psychological Well-being (PW, Ryff, 1989, Spanish version of Díaz et al., 2006).

Three dimensions relevant to the study were selected: Self-acceptance (6 items); Domain of the Environment (5 items); and Purpose in Life (5 items). The response format was $1=$ Strongly agree to $7=$ Strongly disagree. The internal structure of the BP evaluated with 
EFA generated only two dimensions: Psychological Well-being $(\alpha=0.85)$ and

Psychological Distress $(\alpha=0.63)$, explaining $42.37 \%$ of the sum of squared saturations.

Social Well-being (SW, Keyes, 1998, Spanish version of Blanco \& Díaz, 2005).

Two relevant dimensions were selected for the study: Social Integration (5 items) and

Social Actualization (5 items). The response format was $1=$ Strongly agree to $7=$ Strongly disagree. The internal structure showed two dimensions: Social Well-being $(\alpha=0.90)$ and Social Distress $(\alpha=0.66)$, explaining $41.91 \%$ of the sum of squared saturations.

\section{Data Analysis}

In the content validation phase, the data obtained for each item were processed in excel by using the formula to calculate the item-objective agreement index (IC) and the relevance (IP) through the average of the scores assigned for each item. To study the internal structure and consistency of the PSTS as well as divergent validity, we used the SPSS 23 statistical package and the SPSS syntax for parallel analysis proposed by O'Connor (2000). The EFA was chosen because it is the recommended technique when there are no previous systematic results or a solid theoretical model (Izquierdo, Olea \& Abad, 2014). The Kaiser-Meyer-Olkin sample adequacy test (KMO) and Bartlett's sphericity test (1951) were used. The number of retained factors was determined by Horn's (1965). parallel analysis The extraction method was a factorization of the main axis (PE) with direct Oblimin rotation. Internal consistency of the dimensions was calculated by using Cronbach's $\alpha$ coefficients. Pearson correlations were performed with the factorial scores to examine the divergent validity of the PSTS dimensions with the EGEP dimensions, PW and SW. 


\section{Results}

\section{Evidence of content validity}

The degree of the judges' agreement with respect to the 142 items proposed in the booklet was evaluated by using the item-objective agreement index by Rovinelli \& Humbleton (1977) applying the formula proposed by the authors in Figure 1.

Figure 1. Item-objective agreement index

$$
\begin{aligned}
& \qquad I_{j k}=\frac{N}{2 N-2}\left(\bar{X}_{j k}-\bar{X}_{j}\right) \\
& \mathrm{Xjk}=\text { Valuation of the indicator } \mathrm{j} \text { in the dimension u objective } \mathrm{k} \\
& \mathrm{N}=\text { Number of dimensions contemplated in the instrument }
\end{aligned}
$$

If the experts agreed that an item corresponded to the expected dimension $\mathrm{k}$, it was expected that the IC would be close to 1 for that dimension. Each item obtained an IC score and an IP score (relevance) for each dimension. Cut-off points were IC $\geq 0.60$ in a dimension and IP $\geq 7.0$. By using this procedure, 81 items were obtained for the PSTS.

\section{Evidence of the internal structure of the PSTS}

Horn's parallel analysis (1965) was used, generating 100 random datasets with the same number of observations $(N=382)$ and variables $(81)$. The results suggested that 6 factors should be retained. It was proposed as a criterion that each factor should have at least 4 items with loadings equal to or greater than 0.40 . When studying the factorial solutions, it was found that factors 5 and 6 did not reach this criterion, therefore, a solution of 4 satisfactory factors was reached.

Table 2 shows the pattern matrix for the four-factor solution that explains $33.23 \%$ of the sum of squared saturations together with the item-dimension correlation, with an 
adequate sample for the analysis (KMO 0,882; Bartlett's sphericity test $\chi 2_{(3081)}=$ 12767.504, $\mathrm{p}<0.001)$. According to the established criterion, no item had relevant weights in more than one factor. The factors that replicate the proposed theoretical structure were the first factor, Pre-traumatic Situation, comprising 19 items with factor loadings between 0.45 and 0.70 , and the fourth factor, Intergroup Emotions, comprising 9 items with loadings between 0.41 and 0.61 . The second and fourth factors grouped the items in an unexpected way. In the second factor the items showed an increase in negative consequences or reactions as a result of violence on a personal level (e.g., feeling of emptiness: I used to be happy, and now I feel miserable), interpersonal relationships (e.g., distrust in others: I have lost confidence in people), and family (e.g., Living with my family has become increasingly difficult). This dimension was called the Destruction of Sociality and comprised 18 items with loadings between 0.41 and 0.68 . In the third factor, 15 items were grouped with factor loadings between 0.40 and 0.69 . This factor comprised items in the opposite vein that allude to positive reactions or consequences of the experience at the individual level (e.g., $I$ have more confidence in myself) and community (e.g., I discovered that my community is stronger than I thought), which is why it was called the Personal and Collective Selfefficacy dimension. The fourth factor was Intergroup Emotions, comprising 9 items with loadings between 0.40 and 0.58 . The items of this factor were designed for the negative “intergroup emotions" regarding the outgroup (e.g., item 38, It irritates me to see that the people who have done so much damage have not been punished"), which is consistent with the original approach referring to this dimension. The original denomination of the dimension was maintained. Interfactor correlations were all below 0.36 , with the highest being 0.35 between the Pre-traumatic Situation and Personal and Collective Self-Efficacy dimensions. 
Table 2

Pattern matrix, factor weights, and item-test correlations of the PSTS

\begin{tabular}{|c|c|c|c|c|}
\hline & $\begin{array}{c}\text { Pre-traumatic } \\
\text { Situation }\end{array}$ & $\begin{array}{l}\text { Destruction } \\
\text { of Sociability }\end{array}$ & $\begin{array}{l}\text { Personal and } \\
\text { Collective } \\
\text { Self-efficacy }\end{array}$ & $\begin{array}{c}\text { Intergroup } \\
\text { Emotions }\end{array}$ \\
\hline 1: Item 17 & .708 & .068 & .036 & .023 \\
\hline 2: Item 9 & .705 & .021 & .070 & .043 \\
\hline 3: Item 21 & .694 & .189 & .073 & -.077 \\
\hline 4: Item 4 & .676 & .146 & .085 & -.134 \\
\hline 5: Item 11 & .672 & .038 & -.056 & .024 \\
\hline 6: Item 19 & .665 & .160 & .068 & -.072 \\
\hline 7: Item 12 & .644 & .071 & -.027 & .002 \\
\hline 8: Item 3 & .632 & -.077 & -.143 & .203 \\
\hline 9: Item 10 & .621 & .033 & -.046 & -.087 \\
\hline 10: Item 5 & .597 & -.057 & .056 & .119 \\
\hline 11: Item 2 & .586 & .201 & .125 & -.139 \\
\hline 12: Item 18 & .564 & .107 & .155 & .087 \\
\hline 13: Item 1 & .537 & -.092 & .039 & .084 \\
\hline 14: Item 14 & .530 & -.045 & .199 & .236 \\
\hline 15: Item 16 & .504 & -.107 & .023 & .327 \\
\hline 16: Item 7 & .497 & -.125 & .071 & .194 \\
\hline 17: Item 13 & .475 & .108 & .207 & .084 \\
\hline 18: Item 15 & .462 & -.113 & .053 & .361 \\
\hline 19: Item 20 & .456 & .093 & .081 & .086 \\
\hline 20: Item 66 & .032 & .686 & -.124 & -.050 \\
\hline 21: Item 60 & .057 & .659 & -.022 & -.015 \\
\hline 22: Item 53 & -.012 & .597 & -.071 & -.021 \\
\hline 23: Item 45 & -.010 & .594 & -.020 & .066 \\
\hline 24: Item 54 & .138 & .584 & -.004 & .079 \\
\hline 25: Item 58 & -.022 & .578 & -.004 & .108 \\
\hline 26: Item 25 & .223 & .547 & .050 & .052 \\
\hline 27: Item 43 & .160 & .535 & .075 & .133 \\
\hline 28: Item 61 & .018 & .513 & .021 & .059 \\
\hline 29: Item 55 & .004 & .492 & .090 & .134 \\
\hline 30: Item 40 & -.016 & .486 & -.220 & -.002 \\
\hline 31: Item 56 & -.021 & .484 & -.108 & -.075 \\
\hline 32: Item 39 & .093 & .461 & .141 & .091 \\
\hline 33: Item 44 & .101 & .442 & .109 & .042 \\
\hline 34: Item 22 & -.093 & .435 & .013 & -.010 \\
\hline 35: Item 28 & .178 & .420 & .133 & .008 \\
\hline 36: Item 78 & -.127 & .417 & .172 & .133 \\
\hline 37: Item 74 & -.070 & .416 & .079 & .241 \\
\hline 38: Item 48 & .060 & -.094 & .694 & -.063 \\
\hline
\end{tabular}




\begin{tabular}{|c|c|c|c|c|}
\hline 39: Item 79 & .118 & -.137 & .599 & -.004 \\
\hline 40: Item 23 & .083 & .055 & .598 & -.184 \\
\hline 41: Item 41 & .105 & -.044 & .598 & -.065 \\
\hline 42: Item 36 & .077 & .027 & .597 & .001 \\
\hline 43: Item 77 & .085 & -.011 & .590 & .051 \\
\hline 44: Item 34 & -.020 & .134 & .555 & -.105 \\
\hline 45: Item 62 & .195 & -.001 & .516 & -.182 \\
\hline 46: Item 29 & .017 & -.007 & .499 & -.047 \\
\hline 47: Item 32 & .059 & -.070 & .485 & .051 \\
\hline 48: Item 75 & .017 & .095 & .478 & .067 \\
\hline 49: Item 69 & -.100 & -.131 & .474 & .109 \\
\hline 50: Item 67 & -.057 & -.008 & .453 & .006 \\
\hline 51: Item 50 & .112 & -.070 & .451 & .115 \\
\hline 52: Item 71 & .148 & -.051 & .407 & -.016 \\
\hline 53: Item 80 & -.036 & .235 & -.159 & .614 \\
\hline 54: Item 73 & .048 & .170 & -.117 & .575 \\
\hline 55: Item 37 & .144 & -.060 & .009 & .560 \\
\hline 56: Item 63 & -.047 & .178 & -.044 & .545 \\
\hline 57: Item 31 & .055 & -.005 & .020 & .466 \\
\hline 58: Item 81 & .190 & .047 & -.007 & .462 \\
\hline 59: Item 68 & .211 & -.160 & .088 & .438 \\
\hline 60: Item 30 & .123 & .172 & -.089 & .423 \\
\hline 61: Item 38 & .215 & -.019 & .244 & .419 \\
\hline Eigenvalue & 15.559 & 6.780 & 3.821 & 2.635 \\
\hline Cronbach's $\alpha$ & .93 & .89 & .86 & .81 \\
\hline
\end{tabular}

These analyses were confirmed using CFA to study model fit. The results show some acceptable indexes, such as $\chi^{2}(1797)=3384.947, \mathrm{p}<0.001$, and RMSEA $=0.050$ (90\% CI [0.047, 0.052]), and some with less goodness of fit, such as CFI $=0.823$; TLI $=$ $0.814 ; \mathrm{NNFI}=0.814 ; \mathrm{PNFI}=0.654 ; \mathrm{SRMR}=0.071$, which could be explained by a lack of parsimony.

\section{Evidence of validity with other variables}

The dimensions of PSTS coherently and significantly correlated with the dimensions of EGEP, BP, and BS. Table 3 presents the correlation coefficients, which do not exceed 0.60. As expected, the Personal and Collective Self-Efficacy dimension was positively associated with the Psychological Well-being $(r=0.54)$ and Social Integration $(r$ 
$=0.52$ ) dimensions. The Destruction of Sociality presents expected correlations with the Psychological Distress $(r=0.58)$ and Social Distrust $(r=0.35)$ dimensions, as well as Pretraumatic Situation with Cognitive Alterations $(r=0.20)$. Lastly, there is a positive and expected association between Intergroup Emotions and Psychological Distress $(r=0.32)$.

There were unexpected positive significant relationships between Pre-traumatic Situation and Psychological Well-being $(r=0.29)$ and Social Integration $(r=0.26)$, as well as Intergroup Emotions with Psychological Distress $(r=0.31)$ and Psychological Well-being $(r=0.20)$.

Table 3

Correlations between dimensions of the PSTS and dimensions of validation scales, complete sample $(N=382)$

\begin{tabular}{lcccc}
\hline & \multicolumn{4}{c}{ Dimensions PSTS } \\
\cline { 2 - 5 } Dimensions & $\begin{array}{c}\text { Pre-traumatic } \\
\text { Situation }\end{array}$ & $\begin{array}{c}\text { Destruction } \\
\text { of Sociability }\end{array}$ & $\begin{array}{c}\text { Personal and } \\
\text { Collective Self- } \\
\text { efficacy }\end{array}$ & $\begin{array}{c}\text { Intergroup } \\
\text { Emotions }\end{array}$ \\
\hline EGEP & $.204^{* *}$ & .059 & $.133^{*}$ & -.025 \\
Cognitive Alterations & $.151^{* *}$ & .072 & $.177^{* *}$ & -.029 \\
Mood Alterations & $.257^{* *}$ & -.045 & $.519^{* *}$ & $.206^{* *}$ \\
SW & .080 & $.347^{* *}$ & .034 & $.169^{* *}$ \\
Social Integration & $.285^{* *}$ & -.043 & $.536^{* *}$ & $.202^{* *}$ \\
Social Distrust & .074 & $.579^{* *}$ & .051 & $.319^{* *}$ \\
PW & & & & \\
Psychological Well-being & Psychological Distress & & &
\end{tabular}

$* * \mathrm{p}<0,01 ; * \mathrm{p}<0,05$

\section{Discussion}

In the present study, steps were taken to create and validate the PSTS, which assesses the consequences of political violence. Based on Martín-Baró's proposals and the results of previous research in contexts of violence, four dimensions of the TPS were stated: Pre-traumatic Situation, Destruction of Fundamental Beliefs, Intergroup Emotions, and Family and Community Destruction. In the content validation phase, items representing 
these dimensions were designed and content was validated by expert judges, resulting in a preliminary scale of 81 items. This version of the PSTS was applied to adult victims of violence.

The second phase of evidence of internal structure and reliability reduced the PSTS to a 61 item version. It was structured in four dimensions, quite well delimited, with a number of items that fluctuated between 19 and 9 items, and with relevant factorial weights greater than 0.40. The consistency was good for all dimensions, with Cronbach's alpha values above 0.80 and an acceptable model fit in the CFA. The final dimensions of the PSTS were those mentioned above, with two of them differing from those theoretically proposed: Pre-traumatic Situation and Intergroup Emotions.

The "new" dimension of Destruction of Sociality is in line with the original dimension called Destruction of Fundamental Beliefs (individual consequences). In addition, it incorporates consequences to family and community networks belonging to the proposed dimensions of Family and Community Destruction. The emergence of Personal and Collective Self-Efficacy shows that, although most studies have been concerned with the symptoms and problems associated with collective violence, in the last two decades the evidence indicates that associated pathologies are fewer than expected (Bonanno, 2004), and the community belonging and neighborhood cohesion could act as protective factors (Ellis, Abdi, Miller, White, \& Lincoln, 2015).This dimension is part of a vision of trauma that states that its psychosocial impact is composed of the negative and positive effects of events (Leiva-Bianchi, Ahumada, Araneda, \& Botella, 2018) and in these contexts selfefficacy could emerge as a coping strategy (Smith, Felix, Benight, \& Jones, 2017). Although Martín-Baró focused his work on the negative consequences — due to trauma's relevance as a mental health problem and the responsibility of those governments that were 
often victimizers - he also points out that these experiences could contribute to the growth and improvement of individuals (Martín-Baró, 1990) through actions and responses of solidarity and cooperation within affected communities (Martín-Baró, 2003).

These relationships among Psychosocial Well-being and Pre-traumatic Situation with Social Integration, and those among Intergroup Emotions and Social Integration, Social Distrust and Psychological Well-being, may be an expression of emotional ambivalence in trauma contexts (Ben-Zur \& Zimmerman, 2005; Jerg-Bretzke, Walter, Limbrecht-Ecklundt, \& Traue, 2013) and is linked to studies that found evidence of wellbeing in displaced persons in the Colombian context (Blanco \& Amarís, 2014).

A limitation to this study is the possible effect of the method on the Destruction of Sociality and the Personal and Collective Self-Efficacy dimensions, where items with the same valence were grouped (inverted personal and collective self-efficacy items). However, interfactorial correlation between both factors is low $(r=0.10)$. Therefore, the results referring to these dimensions should be interpreted with caution until additional analyses are carried out, as recommended by Tomás, Sancho-Requena, Oliver, Galiana, \& Meléndez (2012). They suggest exploring the presence of this effect through an analysis of the convergent-discriminant validity of the multirate-multimethod matrices from the AFC by using correlated traits and correlated methods (CFA-CTCM). Another alternative would be to apply the model of correlated traits and correlated unicity suggested by Marsh, Balla, \& McDonald (1988) and Marsh (1989).

Validity studies are the first step to a new scale, keeping in mind that the validation process is a continuous process to make sense of score interpretation and the advisable use of a new instrument, such as PSTS. Accordingly, it is necessary to confirm the factorial structure found by carrying out cross-validation studies to verify the stability of the found 
dimensions. Given the results of the CFA related to the indexes measuring parsimony, it would be beneficial to have an even smaller version, considering the most relevant items for each dimension according to their psychometric properties or theoretical relevance. As for the relationship of TPS with other constructs, from the results presented, it is clear that this construct could be contrasted with variables such as individual resilience (Bonanno, 2004: Bonanno \& Mancini, 2008) and, above all, with community resilience (Sharifi, 2016) and individual post-traumatic growth (Calhoun \& Tedeschi, 1999) or collective growth (Wlodarczyk, Basabe, Páez, Villagrán, \& Reyes, 2017). Thus, this construct could elucidate whether the personal and collective self-efficacy dimension corresponds to the concept proposed by Bandura (1997).

Further studies on psychosocial trauma could explore other scenarios where this phenomenon can be important, such as the environmental damage caused by oil extraction in Ecuador (Sanandrés \& Otarola, 2015), the psychosocial effects on indigenous communities caused by the installation of dams in Mexico (Jiménez, 2014), and the impact of massive rail accidents in Uruguay (Loarche, 2015). Therefore, it would be worth to study other sample types that have undergone traumatic experiences. In these cases, the proposed instrument should be revised and adjusted because it is specific to the context of violence.

In summary, the relevance of the study of TPS is confirmed. Moreover, in the future, our scale could be used as a contributing tool to the development of appropriate psychosocial strategies to intervene in these contexts in which individual intervention would be insufficient given the aspects related to the active participation of affected people and communities (Medina, 2015; Haer, Scharpf \& Hecker, 2020). 


\section{References}

American Psychiatric Association (APA). (2013). Diagnostic and Statistical Manual of Mental Disorders (5 ${ }^{r d}$ Ed.). Washington, D.C.: Author.

American Psychiatric Association. (1980). Diagnostic and Statistical Manual of Psychiatric Disorders, (3rd edition) (DSM-lIl). Washington, DC: American Psychiatric Association.

American Psychiatric Association. (1987). Diagnostic and statistical manual of mental disorders (3rd edition-revised) (DSM-III-R), Washington, D.C., American Psychiatric Association. 
Asociación Mundial Médica (1964). Declaración de Helsinki de la AMM. Principios éticos para las investigaciones médicas en seres humanos. Consultado el 26 de septiembre de 2015. Available online at: http://www.who.int/bulletin/archives/79(4)373.pdf

Asociación Mundial Médica (2013). Declaración de Helsinki de la AMM. Principios éticos para las investigaciones médicas en seres humanos. Consultado el 26 de septiembre de 2015. Available online at: http://www.wma.net/es/30publications/10policies/b3/

Bandura, A. (1997). Self-efficacy: The exercise of control. Nueva York: Freeman.

Bartlett, M. S. (1951). The effect of standardization on a $\chi^{2}$ approximation in factor analysis. Biometrika, 38(3/4), 337-344. http://dx.doi.org/10.2307/2332580

Ben-Zur, H., \& Zimmerman, M. (2005). Aging holocaust survivors' well-being and adjustment: Associations with ambivalence over emotional expression. Psychology and Aging, 20(4), 710.

Blanco, A., \& Amarís, M. (2014). La ruta psicosocial del desplazamiento: una perspectiva de $\quad$ Eénero. $\quad$ Pniversitas $\quad$ 661-679. https://doi.org/10.11144/Javeriana. UPSY13-2.rpdu

Blanco, A., \& Díaz, D. (2005). El bienestar social: su concepto y medición. Psicothema, 17(4), 582-589.

Blanco, A., Blanco, R., \& Díaz, D. (2016). Social (dis)order and psychosocial trauma: Look erlier, look inside, and look beyond the persons. American Psychologist. 70 (3). http://dx.doi.org/10.1037/a0040100

Blanco, A., Díaz, D., y del Soto, A. (2006). Recovering the context in posttraumatic stress disorder: The psychosocial trauma in victims of political violence and terrorism. $\begin{array}{llll}\text { Estudios } & \text { de } & \text { Psicología, } & \text { 27(3), }\end{array}$ http://dx.doi.org/10.1174/021093906778965053 
Bonanno, G. A. (2004). Loss, trauma, and human resilience: have we underestimated the human capacity to thrive after extremely aversive events? American Psychologist, 59(1), 20-28. http://dx.doi.org/10.1037/0003-066X.59.1.20

Bonanno, G. A., y Mancini, A.D. (2008). The human capacity to thrive in the face of potential trauma. Pediatrics, 121(2), 369-375. http://dx.doi.org/10.1542/peds.20071648

Braun-Lewenshon, O., \& Al-Sayed, K. (2018). Syrian Adolescent Refugees: How Do They Cope During Their Stay in Refugee Camps? Frontiers in Psychology, 9:1258. https://doi.org/10.3389/fpsyg.2018.01258

Brave Heart, M.Y.H., Chase, J., Elkins, J., \& Altschul, D.B. (2011). Historical Trauma Among Indigenous Peoples of the Americas: Concepts, Research, and Clinical Considerations. Journal of Psychiatric Drugs, 43, 282-290. https://doi.org/10.1080/02791072.2011.62891Centro Nacional de Memoria Histórica (CNMH) (2013). ¡BASTA YA! Colombia: memorias de guerra y dignidad [iBASTA YA! Colombia: Memories of War and dignity]. Bogotá: Centro Nacional de Memoria Histórica.

Calhoun. L. G., y Tedeschi. R.G. (1999). Facilitating posttraumatic growth: A clinician`s guide. Nueva Jersey: Lawrence Erlbaum Associales. Inc.

Comas-Díaz, L., Hall, G. N., \& Neville, H. A. (2019). Racial trauma: Theory, research, and healing: Introduction to the special issue. American Psychologist, 74(1), 1. http://dx.doi.org/10.1037/amp0000442

Crespo, M., y Gómez, M. (2012). La evaluación del estrés postraumático: Presentación de la escala de evaluación global de estrés postraumático (EGEP). Clínica y Salud, 23(1), 25-41. http://dx.doi.org/10.5093/cl2012a4 
Díaz, D., Rodríguez-Carvajal, R., Blanco, A. Moreno-Jiménez, B., Gallardo, I., Valle, C., y Van Dierendonck, D. (2006). Adaptación española de las escalas de bienestar psicológico de Ryff. Psicothema, 18(3), 572-577.

Díaz, D., Stavraki, M., Blanco, A., \& Bajo, M. (2018). 11-M Victims 3 Years After Madrid Terrorist Attacks: Looking for Health Beyond Trauma. Journal of Happiness Studies, 19, 663-675. https://doi.org/10.1007/s10902-016-9842x

Ellis, B. H., Abdi, S. M., Miller, A. B., White, M. T., \& Lincoln, A. K. (2015). Protective factors for violence perpetration in Somali young adults: The role of community belonging and neighborhood cohesion. Psychology of Violence, 5(4), 384392. https://doi.org/10.1037/a0039610

Freitas, D. F., Fernandes-Jesus, M., Ferreira, P. D., Coimbra, S., Teixeira, P. M., de Moura, A., Gato, J., Marques, S. C., \& Fontaine, A. M. (2018). Psychological correlates of perceived ethnic discrimination in Europe: A meta-analysis. Psychology of Violence, 8(6), 712-725. https://doi.org/10.1037/vio0000215

Haer, R., Scharpf, F., \& Hecker, T. (2020). The social legacies of conflict: The mediating role of mental health with regard to the association between war exposure and social capital of Burundian refugees. Psychology of Violence. Advance online publication. https://doi.org/10.1037/vio0000348

Horn, J. L. (1965). A rationale and test for the number of factors in factor analysis. Psychometrika, 30(2), 179-185. http://dx.doi.org/10.1007/BF02289447

ILAS (Instituto Latinoamericano de Salud Mental y Derechos Humanos) (1990). Derechos Humanos: todo es según el color con que se mira [Human Rights: Everything is in the eye of the beholder]. Santiago de Chile: ILAS. 
Izquierdo, I., Olea, J., \& Abad, F. J. (2014). Exploratory factor analysis in validation studies: Uses and recommendations. Psicothema, 26(3), 395-400. https://doi.org/10.7334/psicothema2013.349

Jiménez, B. (2014). Efectos psicosociales anticipados del proyecto de presa El Zapotillo sobre los habitantes de Temacapulín. En En Flores, J. (Ed.), Repensar la psicología y lo comunitario en América Latina (pp.137-170). Tijuana: Universidad de Tijuana CUT.

Keyes, C. L. M. (1998). Social well-being. Social Psychology Quarterly, 61(2), 121-140. http://dx.doi.org/10.2307/2787065

Leiva-Bianchi, M., Ahumada, F., Araneda, A., \& Botella, J. (2018). What is the psychosocial impact of disasters? A meta-analysis. Issues in mental health nursing, 39(4), 320-327. https://doi.org/10.1080/01612840.2017.1393033

Lira, E. (1994). Psicología y violencia política en América Latina [Psychology and political violence in Latin America]. Santiago de Chile. ILAS.

Loarche, G. (2015). Impacto vital en experiencias extremas: estudio sobre el trauma psicosocial de los habitantes de la ciudad de Young en relación al siniestro ferroviario del año 2006 (Master's Thesis). Universidad de la República, Montevideo, Uruguay.

Madariaga, C. (2002). Trauma psicosocial, trastorno de estrés postraumático y tortura. Santiago, Chile: Ediciones CINTRAS.

Marsh, H. W., Balla, J. R., \& McDonald, R. P. (1988). Goodness-of-fit indexes in confirmatory factor analysis: The effect of sample size. Psychological Bulletin, 103(3), 391-410. http://dx.doi.org/10.1037/0033-2909.103.3.391 
Marsh, H.W. (1989). Confirmatory factor analysis of multitraitmultimethod data: Many problems and a few solutions. Applied Psychological Measurement, 13, 335-361. https://doi.org/10.1177/014662168901300402

Martín-Baró, I. (1990). Psicología social de la Guerra: trauma y terapia. El Salvador: UCA.

Martín-Baró, I. (2003). Poder, ideología y violencia. Madrid: Ediciones Trotta.

Médicos Sin Fronteras (2013). Las heridas menos visibles: Salud mental, violencia y conflicto armado en el sur de Colombia [The least visible wounds: mental health, violence and armed conflicto in Southern Colombia]. Bogotá: Author.

Medina, J. L. (2015). Trauma psíquico. Madrid: Ediciones Paraninfo, SA. http://dx.doi.org/10.1023/A:1020181124118

O’Connor, B. P. (2000). SPSS and SAS programs for determining the number of components using parallel analysis and Velicer's MAP test. Behavior Research Methods, Instruments, y Computers, 32(3), 396-402. https://doi.org/10.3758/BF03200807

Oficina de Derechos Humanos del Arzobispado de Guatemala (ODHAG) (1998). NUNCA MÁS. Impactos de la violencia [NEVER AGAIN. Impacts of violence]. Guatemala: Author.

Peltonen, K., Qouta, S., El Sarraj, E., \& Punamäki, R. L. (2010). Military trauma and social development: The moderating and mediating roles of peer and sibling relations in mental health. International Journal of Behavioral Development, 34(6), 554-563. https://doi.org/10.1177/0165025410368943

Robben, A. C. (2008). Pegar donde más duele. Violencia política y trauma social en Argentina. Barcelona: Anthropos. 
Rovinelli, R. J., \& Hambleton, R. K. (1977). On the use of content specialists in the assessment of criterion-referenced test item validity. Dutch Journal of Educational Research, 2, 49-60.

Ryff, C. D. (1989). Happiness is everything, or is it? Explorations on the meaning of psychological well-being. Journal of Personality and Social Psychology, 57(6), 1069-1081. http://dx.doi.org/10.1037/0022-3514.57.6.1069

Sanandrés, E., y Otálora, J. (2015). Una aplicación de topic modeling para el estudio del trauma: El caso de Chevron-Texaco en Ecuador. Investigación y Desarrollo, 23(2), 228-255.

Sharifi, A. (2016). A critical review of selected tools for assessing community resilience. Ecological Indicators, 69, 629-647. http://dx.doi.org/10.1016/j.ecolind.2016.05.023

Smith, A. J., Felix, E. D., Benight, C. C., \& Jones, R. T. (2017). Protective factors, coping appraisals, and social barriers predict mental health following community violence: a prospective test of social cognitive theory. Journal of traumatic stress, 30(3), 245253. http://dx.doi.org/10.1002/jts.22197

Somasundaram, D. (2005). Short-and Long-Term Effects on the Victims of Terror in Sri Lanka. In Y. Danieli, D. Brom, \& J. Sills (Eds.), The Trauma of Terrorism. Sharing Knowledge and Shared Care. An International Handbook (pp. 215-228).

Tomás, J. M., Sancho-Requena, P., Oliver, A., Galiana, L. \& Meléndez, J. C. (2012). Efectos de método asociados a ítems invertidos vs. ítems en negativo. Revista Mexicana de Psicología, 29(2), 105-115.

Vázquez, C. (2005). Reacciones de estrés en la población general trás los ataques terroristas del 11S, 2001 (EE.UU) y del 11M, 2004 (Madrid, España): Mitos y realidades. Anuario de Psicología Clínica y de la Salud, 1, 9-25. 
Villagrán, L. (2016). Trauma psicosocial: Naturaleza, dimensiones y medición (Doctoral thesis). Universidad Autónoma de Madrid. Madrid, España.

Whitbeck, L.B., Adams, G.W., Hoyt, D.R., \& Chen, X. (2004). Conceptualizing and Measuring Historical Trauma Among American Indian People. American Journal of Community Psychology, 33, 119-130.

http://dx.doi.org/10.1023/B:AJCP.0000027000.77357.31

Wlodarczyk, A., Basabe, N., Páez, D., Villagrán, L., \& Reyes, C. (2017). Individual and collective posttraumatic growth in victims of natural disasters: a multidimensional perspective. Journal of loss and trauma, 22(5), 371-384.

http://dx.doi.org/10.1080/15325024.2017.1297657 